\title{
Clinical Pharmacy Services Provided in Public Sector Hospitals in Nigeria: A National Survey
}

Authors: Arit Udoh ${ }^{1 *}$, Mary Akpan², Umar Idris Ibrahim ${ }^{3,4}$, Basira Kankia Lawal ${ }^{5}$, Kamilu Sarki Labaran ${ }^{4}$, Ekpedeme Ndem², Kosisochi Amorha ${ }^{6}$, Ayodeji Matuluko ${ }^{7}$, Olubukola Tikare ${ }^{8}$, Unoma Ohabunwa ${ }^{8}$, Eneyi Kpokiri $^{9}$

${ }^{1}$ College of Medical and Dental Sciences, University of Birmingham, Birmingham, United Kingdom

${ }^{2}$ Faculty of Pharmacy, University of Uyo, Akwa Ibom State, Nigeria

${ }^{3}$ Department of Clinical Pharmacy and Pharmacy Practice, Bayero University, Kano, Nigeria

${ }^{4}$ Department of Clinical Pharmacy and Pharmacy Practice, Ahmadu Bello University, Zaria, Nigeria

${ }^{5}$ Department of Clinical Pharmacy and Pharmacy Management, Kaduna State University, Kaduna, Nigeria

${ }^{6}$ Department of Clinical Pharmacy \& Pharmacy Management, University of Nigeria Nsukka, Enugu, Nigeria

${ }^{7}$ School of Health and Life Sciences, Glasgow Caledonian University, Glasgow, United Kingdom

${ }^{8}$ Department of Pharmacy, Federal Medical Centre, Abuja, Federal Capital Territory, Nigeria

${ }^{9}$ Faculty of Infectious and Tropical Diseases, London School of Hygiene and Tropical Medicine, London, United Kingdom 
medRxiv preprint doi: https://doi.org/10.1101/2021.06.17.21258942; this version posted June 21, 2021. The copyright holder for this preprint (which was not certified by peer review) is the author/funder, who has granted medRxiv a license to display the preprint in perpetuity.

It is made available under a CC-BY-NC-ND 4.0 International license .

\section{ABSTRACT}

Background: Studies show that clinical pharmacy services are effective in optimizing medicines use and patients' outcomes. This study aimed to determine the clinical pharmacy services provided in public sector hospitals in Nigeria.

Methods: This was an online survey of 296 primary, secondary and tertiary care hospitals sampled purposively across the 36 States and Federal Capital Territory in Nigeria. Data analysis was conducted descriptively, and via Chi-square test and multivariate analysis of variance (MANOVA).

Key findings: Responses were obtained from 272 hospitals in the country with a survey completion rate of $88 \%$. This included 55 tertiary, 72 secondary, and 145 primary healthcare centres (PHCs). Pharmacists provided pharmaceutical care services in all the tertiary care hospitals, $94 \%$ of the secondary, and in only $6 \%$ of the PHCs surveyed. The composition of the pharmacy department per level of care was similar across the six geopolitical regions $(\mathrm{V}=0.383, \mathrm{~F}=1.453, \mathrm{P}=0.06)$ with more pharmacy staff employed in the tertiary care hospitals compared to the secondary care facilities. The majority $(\geq 75 \%)$ of the tertiary and secondary care hospitals provided medicines information, patient education and counselling, alongside in- and outpatient dispensing services. However, fewer than 30\% reported routine pharmacists' involvement in multidisciplinary ward rounds, medication chart review, therapeutic guidelines development, antibiotic stewardship programmes, and drug therapy monitoring. Pharmacists routinely provided medication error reporting services in only about half of the hospitals in the sample, and this was not associated with the level of care $(p>0.05)$.

Conclusions: The findings of this study demonstrate disparity in clinical pharmacy service availability across the various levels of care in Nigeria. It also highlights the need to scale up and prioritize their integration within the primary care sector.

Keywords: Clinical pharmacy, pharmaceutical care, primary care, Nigeria 
medRxiv preprint doi: https://doi.org/10.1101/2021.06.17.21258942; this version posted June 21, 2021. The copyright holder for this preprint (which was not certified by peer review) is the author/funder, who has granted medRxiv a license to display the preprint in perpetuity.

It is made available under a CC-BY-NC-ND 4.0 International license .

\section{INTRODUCTION}

In November 2019, the National Council on Establishments (NCE) approved the consultant pharmacist cadre for inclusion in the public sector schemes of service in Nigeria [1]. This approval was assented to by the Head of the Federal Civil Service in September 2020 [1], and represents government acknowledgement of the essential role of pharmacists as medicines experts within the multidisciplinary clinical team. This acknowledgement underscores pharmacists' evolving roles from the focus on medicines and medicinal products, to the provision of patient-oriented services. Globally, this patient-oriented practice model, which is the concept of clinical pharmacy; has been shown to optimize medicines use, assure medication safety, and improve patients' outcomes and quality of life [2].

Although clinical pharmacy is well established in several high income countries [3-7]; its uptake has varied across the world regions and within nations [8-11]. Until recently, the delivery of these services in countries in Africa has been limited and/or non-existent [12-14]. The revised Basel Statements on the Future of Hospital Pharmacy, published in 2014, emphasized the pharmacists' role in the clinical team, including their influence on prescribing and monitoring of medicines use $[15,16]$. The increasing involvement in patient-oriented service provision underscores the imperative for the availability of appropriately trained pharmacists equipped with the requisite skills needed to provide enhanced pharmaceutical care.

In Nigeria, estimates show that hospital pharmacists make up about $20 \%$ of the licensed pharmacy workforce [17]. Although data on the distribution of pharmacists across the private and public sector hospitals in the country is lacking in the literature; anecdotally, majority of the hospital pharmacists are employed in the public sector facilities. Also, most of the internship and post-graduate clinical training of pharmacists are carried out at these hospitals. However, information on the pharmaceutical care services provided, and the involvement of hospital pharmacists in patient-oriented care is unclear. A previous study of hospital pharmacy practice in four States in the North Western region of Nigeria estimates that pharmaceutical care services are provided in about $47-85 \%$ of the facilities surveyed per state [18]. This information is missing in the literature for the other parts of the country. Given the paucity of data, this study aimed to determine the clinical pharmacy services provided in public sector hospitals in Nigeria. The findings of this study will inform national policy planning in relation to these services. 
medRxiv preprint doi: https://doi.org/10.1101/2021.06.17.21258942; this version posted June 21, 2021. The copyright holder for this preprint (which was not certified by peer review) is the author/funder, who has granted medRxiv a license to display the preprint in perpetuity.

It is made available under a CC-BY-NC-ND 4.0 International license .

\section{METHOD}

\section{Study setting}

Nigeria is the most populous country in Africa with a population of approximately 200 million [19]. The country is divided in to six geopolitical zones and comprise the Federal Capital Territory (FCT), 36 States, and 774 Local Governments Areas (LGAs). About two-thirds of the hospitals in the country are government owned with the public sector primary, secondary and tertiary care facilities funded by the local, state and federal governments, respectively [20,21]. Government owned primary care facilities are mainly situated in rural areas and comprise the health centres and health posts [22]. In contrast, public sector secondary and tertiary care facilities are predominantly located in urban/peri-urban areas. The district and general hospitals make up the secondary care facilities in the country while tertiary care providers include the teaching hospitals, federal medical centres (FMCs), and other federal funded facilities. The public sector tertiary care facilities are designed to serve as referral hospitals for complex and specialised care provision while the primary care facilities provide basic and preventative health care services $[23,24]$. However, poor funding, limited health infrastructure, as well as staffing and medicines shortages at the primary and in most secondary care hospitals, has led to a preference for tertiary care service providers in population health seeking in Nigeria [24].

\section{Study design}

This study was an online survey of public sector hospitals in Nigeria. The survey included public sector primary, secondary and tertiary care hospitals sampled across the 36 States and the FCT. To ensure that all the states and FCT in the country were duly represented in the survey; the hospitals per state were sampled purposively. Specifically, the Nigeria Health Facility Registry of the Federal Ministry of Health [25] was consulted to identify the public sector hospitals in the country. Thereafter, all the teaching hospitals and FMCs listed were targeted for data collection. Where feasible, data from an additional federal government funded facility in each State were also collected to make up two tertiary care hospitals. In addition, two general hospitals and four primary healthcare centres (PHCs)/health posts in each of the states were targeted. In total, 74 tertiary and secondary care facilities each, and $148 \mathrm{PHCs} /$ health posts were targeted. 
medRxiv preprint doi: https://doi.org/10.1101/2021.06.17.21258942; this version posted June 21, 2021. The copyright holder for this preprint (which was not certified by peer review) is the author/funder, who has granted medRxiv a license to display the preprint in perpetuity.

It is made available under a CC-BY-NC-ND 4.0 International license .

\section{Data collection}

Data collection was via the online Qualtrics ${ }^{\circledR}$ software (Qualtrics, Utah, USA). The hospital administrator, head of the pharmacy department or a designated senior pharmacist with managerial responsibility at each target facility provided data for the survey. Respondents for this survey were identified via the Association of Hospital and Administrative Pharmacists of Nigeria (AHAPN), the state chapters of the Pharmaceutical Society of Nigeria (PSN), and through the authors' professional network. The online survey link was shared with each respondent with consent to participate required prior to data completion. This survey was conducted over 12 months and data collection concluded on 30 July 2020. Ethical review and approval for this study was obtained from the National Health Research Ethics Committee (NHREC) of the Federal Ministry of Health in Nigeria (REF NO: NHREC/01/01/2007).

\section{Survey Instrument}

The data collection tool (provided in Appendix 1) was adapted from a previously validated instrument used in a survey of hospital pharmacy practice in Ireland [7]. The adapted questionnaire was pre-tested for face and content validity in a sample of five pharmacists who were not directly involved in this study. Feedback obtained from the pre-test was incorporated with further iteration resulting in a questionnaire comprising 23 items that required a combination of multiple choice, "Yes", "No", "Not applicable", or free text responses. The survey questions were presented over five pages. The first page of the questionnaire included a consent question that required an affirmative answer to be eligible to participate.

To ensure completeness, all the survey questions were mandatory. Respondents had to provide an answer to the questions on a given page in order to proceed to the next. Given the objective of this study and to ensure a meaningful interpretation of the survey findings; a filtering question was employed. The provision of pharmaceutical care services by pharmacist at each facility was the filtering question used. This question was presented in the demographic section on page 2 , and respondents who answered "No" were automatically taken to the end of the survey.

\section{Data Analysis}

Quantitative data obtained in this study were analysed using SPSS v26 (IBM, USA). Descriptive statistics including frequency (counts, percentages), mean (standard deviation (SD)), median (interquartile range (IQR)) were used to summarize the data while the Pearson's Chi-square $\left(X^{2}\right)$ was used to assess association 
medRxiv preprint doi: https://doi.org/10.1101/2021.06.17.21258942; this version posted June 21, 2021. The copyright holder for this preprint (which was not certified by peer review) is the author/funder, who has granted medRxiv a license to display the preprint in perpetuity.

It is made available under a CC-BY-NC-ND 4.0 International license .

between categorical variables. Disparity in the composition of the pharmacy department and the availability of clinical pharmacy services per level of care across the six geopolitical zones in the country, was assessed using the Pillai's Trace statistic ( $V$ ) of the multivariate analysis of variance (MANOVA). The Pillai's Trace multivariate statistic was chosen because it is more robust to outliers and violation of normality [26]. Confirmatory post-hoc analysis was also conducted using the Bonferroni correction. The findings of this survey are reported in line with the Checklist for Reporting Results of Internet E-Surveys (CHERRIES) guidelines [27].

\section{RESULTS}

In total, 308 respondents accessed the online survey link on Qualtrics and consented to participate in the study. Of this number, 272 provided complete responses to the survey questions, indicating a completion rate of $88 \%$. The 36 incomplete responses included those who consented to participate on the first page of the questionnaire but did not attempt the survey questions $(n=11)$, and others who attempted only some of the demographic questions $(n=25)$. The incomplete responses were not useable and were therefore excluded from further analysis.

\section{Demography}

Of the 272 complete responses obtained, 55 were from tertiary care facilities and comprised all the teaching hospitals, FMCs and 11 other government-funded hospitals in the country; 72 were secondary care providers and these were all general hospitals, while the remaining 145 were PHCs. Geographically, responses were obtained from hospitals across the 36 States in the country including the FCT. Regionally, the highest number of responses were from hospitals in the North West ( $n=51,19 \%)$ while the least were from the South East $(n=36,13 \%)$ regions (Table 1).

\section{Hospital profile}

Median hospital size with respect to number of beds varied across the three levels of care. The tertiary care facilities in the sample were generally larger compared to the secondary and primary care hospitals (Table 1). The size of the hospital was also reflected by the number of dispensing locations available. The PHCs and about $72 \%$ of the secondary care facilities had between one to three dispensing locations for pharmaceuticals while the majority (89\%) of the tertiary care facilities had about four or more (Table 1 ). Pharmaceutical care services were provided by pharmacists in all (100\%) of the tertiary facilities, and in 
medRxiv preprint doi: https://doi.org/10.1101/2021.06.17.21258942; this version posted June 21, 2021. The copyright holder for this preprint (which was not certified by peer review) is the author/funder, who has granted medRxiv a license to display the preprint in perpetuity.

It is made available under a CC-BY-NC-ND 4.0 International license .

most of the secondary care hospitals ( $N=68,94 \%)$. However, pharmacists were only available in fewer than $10 \%$ of the PHCs in this survey (Table 1). Given the objective of this study, which was to determine the clinical pharmacy services provided; only the data obtained in the tertiary and secondary care facilities were further analysed hereafter.

Table 1: Hospital Profile and demography

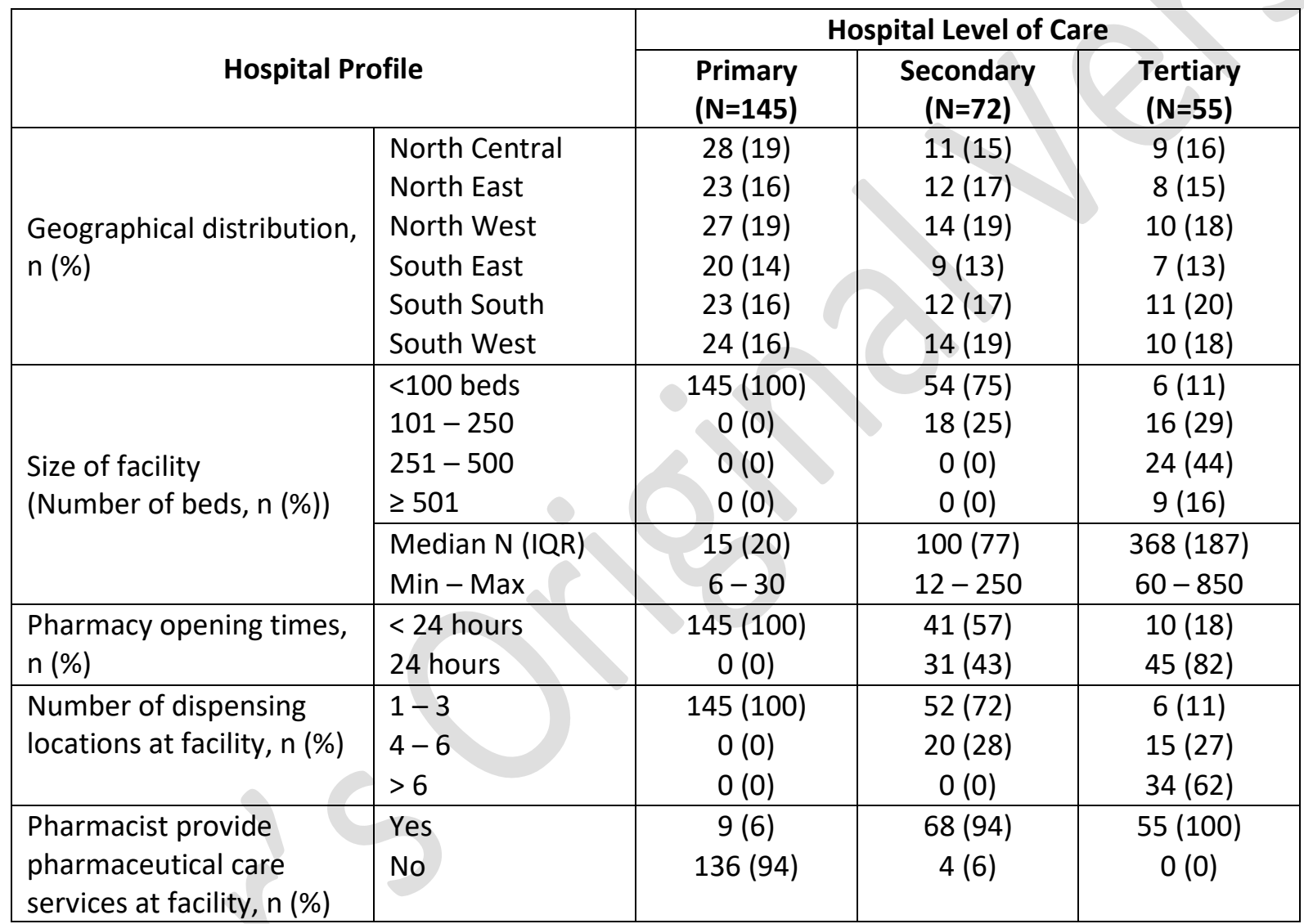

\section{Pharmacy department profile}

This section of the analysis included all the tertiary and the 68 secondary care hospitals that reported that pharmaceutical care services were provided by pharmacists $(N=123)$. Generally, the composition of the pharmacy department was comparative across the six geopolitical regions in the country $(\mathrm{V}=0.383, \mathrm{~F}=$ $1.453, P=0.06)$ with no statistical significant difference observed beyond the level of care provided in the respective hospitals $(\mathrm{V}=0.522, \mathrm{~F}=18.378, \mathrm{P}=0.001)$. The total number of pharmacy staff in the respective cohorts varied with more pharmacists, pharmacy technicians and support staff employed in the tertiary 
medRxiv preprint doi: https://doi.org/10.1101/2021.06.17.21258942; this version posted June 21, 2021. The copyright holder for this preprint (which was not certified by peer review) is the author/funder, who has granted medRxiv a license to display the preprint in perpetuity.

It is made available under a CC-BY-NC-ND 4.0 International license .

care hospitals compared to the secondary care facilities (Table 2). This was reflective of the size of the hospitals in the respective cohorts. More than $70 \%$ of the pharmacists employed in the tertiary care hospitals were those with five or more years of practice experience, compared to the secondary care cohort with about $57 \%$ (Table 2). A higher proportion of the pharmacists in the tertiary care cohort had a post-graduate degree or professional recognition compared to the secondary care with about a third (Table 2).

About half of the secondary care cohort reported a centralized drug distribution system compared to the approximately $60 \%$ in the tertiary care respondents that reported a decentralized or a patient-oriented drug distribution system (Table 2). Pharmacist-led outpatient clinics were available in only four (3\%) hospitals in the sample. Relative to the secondary care hospitals, other outpatient clinics with significant pharmacists' input beyond dispensing were reported in more of the tertiary care hospitals (Table 2), however, this was not statistically significant $\left(X^{2}=2.45, P=0.12\right)$ (Table 2$)$. On the other hand, sexual health clinics with significant pharmacists' input were more likely to be available in secondary care $\left(X^{2}=\right.$ 13.59, $\mathrm{P}=0.001)$, while oncology clinics were more likely to be reported in the tertiary care hospitals $\left(\mathrm{X}^{2}\right.$ $=8.46, \mathrm{P}=0.004)($ Table 2$)$. 
medRxiv preprint doi: https://doi.org/10.1101/2021.06.17.21258942; this version posted June 21, 2021. The copyright holder for this preprint (which was not certified by peer review) is the author/funder, who has granted medRxiv a license to display the preprint in perpetuity.

It is made available under a CC-BY-NC-ND 4.0 International license .

Table 2: Pharmacy department profile per level of care

\begin{tabular}{|c|c|c|c|}
\hline \multirow[t]{2}{*}{ Pharmacy Profile } & \multicolumn{2}{|c|}{$\begin{array}{l}\text { Hospital Level of } \\
\text { Care }\end{array}$} & \multirow{2}{*}{$\begin{array}{c}\text { Total } \\
\text { sample } \\
(\mathrm{N}=123)\end{array}$} \\
\hline & $\begin{array}{l}\text { Secondary } \\
(\mathrm{N}=68)\end{array}$ & $\begin{array}{l}\text { Tertiary } \\
(\mathrm{N}=55)\end{array}$ & \\
\hline \multirow{3}{*}{$\begin{array}{lr}\text { Pharmacy staff gender profile, } & \text { Ma } \\
\text { mean percent }( \pm S D) & \text { Fema } \\
\text { Number of licensed pharmacists employed at facility, mean } \\
( \pm S D)\end{array}$} & $53(24)$ & $50(19)$ & $52(22)$ \\
\hline & $47(24)$ & $50(19)$ & $48(22)$ \\
\hline & $5(5)$ & $30(22)$ & $16(16)$ \\
\hline $\begin{array}{l}\text { Number of pharmacy technicians employed at facility, mean } \\
( \pm S D)\end{array}$ & $4(4)$ & $9(8)$ & $7(7)$ \\
\hline Number of pharmacy support staff, mean $( \pm S D)$ & $3(3)$ & $11(10)$ & $7(6)$ \\
\hline $\begin{array}{l}\text { Proportion of pharmacists with }<5 \text { years' experience, mean } \\
\text { percent }( \pm S D)\end{array}$ & $43(35)$ & $27(19)$ & $32(28)$ \\
\hline $\begin{array}{l}\text { Proportion of pharmacists with } 5-10 \text { years' experience, mean } \\
\text { percent }( \pm S D)\end{array}$ & $37(32)$ & $35(19)$ & $39(25)$ \\
\hline $\begin{array}{l}\text { Proportion of pharmacists with }>10 \text { years' experience, mean } \\
\text { percent }( \pm S D)\end{array}$ & $20(28)$ & $38(27)$ & $29(26)$ \\
\hline $\begin{array}{l}\text { Proportion of pharmacists with post-graduate qualification or } \\
\text { professional recognition, mean percent }( \pm S D)\end{array}$ & $22(21)$ & $51(31)$ & $34(33)$ \\
\hline \multirow{2}{*}{$\begin{array}{lr}\text { Compendial and drug reference } & \text { Yes, } \mathrm{n}(\%) \\
\text { resources available at facility } & \text { No, } \mathrm{n}(\%)\end{array}$} & $62(91)$ & $53(96)$ & $115(93)$ \\
\hline & $6(9)$ & $2(4)$ & $8(7)$ \\
\hline \multirow{2}{*}{$\begin{array}{l}\text { Access to online medicine } \\
\text { information }\end{array}$} & $29(43)$ & $40(73)$ & $69(56)$ \\
\hline & $39(57)$ & $15(27)$ & $54(44)$ \\
\hline \multirow{2}{*}{$\begin{array}{lr}\text { Drug distribution system } & \text { Centralized, } \mathrm{n}(\%) \\
\text { available at facility } & \text { Decentralized, } \mathrm{n}(\%)\end{array}$} & $34(50)$ & $22(40)$ & $56(46)$ \\
\hline & $12(18)$ & $25(45)$ & $37(30)$ \\
\hline $\begin{array}{r}\text { Patient-oriented service, } \mathrm{n} \\
(\%)\end{array}$ & $22(32)$ & $8(15)$ & $30(24)$ \\
\hline \multirow{3}{*}{$\begin{array}{lr}\text { Pharmacist-led outpatient clinic } & \text { Yes, n (\%) } \\
\text { available at site } & \text { No, n (\%) } \\
\text { Outpatient clinic with significant } & \text { Yes, n (\%) }\end{array}$} & $1(2)$ & $3(6)$ & $4(3)$ \\
\hline & $67(98)$ & $52(94)$ & 119 (97) \\
\hline & $43(63)$ & $42(76)$ & $85(69)$ \\
\hline $\begin{array}{ll}\begin{array}{l}\text { Outpatient clinic with significant } \\
\text { pharmacist input available at site }\end{array} & \text { Yes, n (\%) } \\
\text { No, n (\%) }\end{array}$ & $25(37)$ & $13(24)$ & $38(31)$ \\
\hline \multirow{4}{*}{$\begin{array}{lr}\text { Type of outpatient clinic with } & \text { HIV/AIDs, } \mathrm{n}(\%) \\
\text { significant pharmacist input } & \text { Sexual health, } \mathrm{n}(\%) \\
& \text { Tuberculosis, } \mathrm{n}(\%) \\
\text { Oncology, } \mathrm{n}(\%)\end{array}$} & $42(62)$ & 37 (67) & $79(64)$ \\
\hline & $18(26)$ & $1(2)$ & $19(15)$ \\
\hline & $15(22)$ & $14(25)$ & $29(24)$ \\
\hline & $2(3)$ & $10(18)$ & $12(10)$ \\
\hline
\end{tabular}

*SD $=$ Standard deviation 
medRxiv preprint doi: https://doi.org/10.1101/2021.06.17.21258942; this version posted June 21, 2021. The copyright holder for this preprint (which was not certified by peer review) is the author/funder, who has granted medRxiv a license to display the preprint in perpetuity.

It is made available under a CC-BY-NC-ND 4.0 International license .

\section{Clinical pharmacy services provided}

The study showed that medicines information, patient education and counselling, in-patient and outpatient dispensing services were always available in the majority ( $\geq 75 \%)$ of the tertiary and secondary care hospitals in the sample (Table 3). However, fewer than a third of the respondents in either cohort indicated that pharmacists were routinely involved in multidisciplinary ward rounds, therapeutic guidelines development, antibiotic stewardship programmes, anticoagulant services, drug therapy monitoring, clinical trials, and parenteral nutrition service provision (Table 3). Comparatively, discharge counselling, drug utilization evaluation and review, compounding/extemporaneous preparations, and medical device services were more likely to be available in the tertiary care hospitals while vaccines services were more likely to be provided in the secondary care hospitals $(p<0.05)$ (Table 3$)$. Only about half of the hospitals in the overall sample reported the availability of a medication error, pharmacovigilance/adverse drug events $(A D E)$ or adverse drug reaction (ADR) reporting service, and this was not associated with the level of care $(p>0.05)$ (Table 3$)$. 
1 Table 3: Availability of clinical pharmacy services per level of care (*statistical significance $p<0.05)$

\begin{tabular}{|c|c|c|c|c|c|c|c|c|c|c|c|c|c|c|}
\hline \multirow{4}{*}{ Clinical pharmacy services provided } & \multicolumn{12}{|c|}{ Hospital Level of Care } & \multirow{4}{*}{$x^{2}$} & \multirow{4}{*}{$\mathbf{P}$} \\
\hline & \multirow{2}{*}{\multicolumn{2}{|c|}{ Never }} & \multicolumn{4}{|c|}{ econdary $(\mathrm{N}=68)$} & \multicolumn{6}{|c|}{ Tertiary $(\mathrm{N}=55)$} & & \\
\hline & & & & & & & & & $\mathrm{Ra}$ & & & ays & & \\
\hline & $\mathrm{n}$ & $\%$ & $\mathrm{n}$ & $\%$ & $\mathrm{n}$ & $\%$ & $\mathrm{n}$ & $\%$ & $\mathrm{n}$ & $\%$ & $\mathrm{n}$ & $\%$ & & \\
\hline Multidisciplinary ward rounds & 31 & 46 & 28 & 41 & 9 & 13 & 27 & 49 & 19 & 35 & 9 & 16 & 0.574 & 0.751 \\
\hline Medication Chart review & 25 & 37 & 23 & 34 & 20 & 29 & 18 & 33 & 24 & 44 & 13 & 24 & 1.398 & 0.491 \\
\hline Medication error reporting & 9 & 13 & 23 & 34 & 36 & 53 & 5 & 9 & 24 & 44 & 26 & 47 & 1.742 & 0.481 \\
\hline $\begin{array}{l}\text { Therapeutic guidelines and protocol } \\
\text { development }\end{array}$ & 26 & 38 & 28 & 41 & 14 & 21 & 22 & 40 & 22 & 40 & 11 & 20 & 0.01 & 0.995 \\
\hline Inpatient dispensing & 12 & 18 & 13 & 19 & 43 & 63 & 7 & 13 & 3 & 5 & 45 & 82 & 6.599 & $0.037^{*}$ \\
\hline Outpatient dispensing & 0 & 0 & 0 & 0 & 68 & 100 & 0 & 0 & 0 & 0 & 55 & 100 & 0 & 1 \\
\hline Medicines information & 0 & 0 & 10 & 15 & 58 & 85 & 0 & 0 & 11 & 22 & 39 & 78 & 3.107 & 0.078 \\
\hline Antimicrobial stewardship & 35 & 51 & 26 & 38 & 7 & 10 & 18 & 33 & 22 & 40 & 15 & 27 & 7.761 & $0.021^{*}$ \\
\hline Contraceptive services & 35 & 51 & 17 & 25 & 16 & 24 & 26 & 47 & 18 & 33 & 11 & 20 & 0.999 & 0.607 \\
\hline Vaccines services & 13 & 19 & 12 & 18 & 43 & 63 & 19 & 35 & 19 & 35 & 17 & 31 & 12.179 & $0.002 *$ \\
\hline Cold chain management & 9 & 13 & 10 & 15 & 49 & 72 & 11 & 20 & 8 & 15 & 36 & 65 & 1.135 & 0.567 \\
\hline Anticoagulant services & 46 & 68 & 16 & 24 & 6 & 9 & 25 & 45 & 14 & 25 & 16 & 29 & 9.947 & $0.007^{*}$ \\
\hline Medical devices services & 31 & 46 & 14 & 21 & 23 & 34 & 8 & 15 & 22 & 40 & 25 & 45 & 14.87 & $0.001^{*}$ \\
\hline $\begin{array}{l}\text { Compounding/Extemporaneous } \\
\text { preparation }\end{array}$ & 18 & 26 & 32 & 47 & 18 & 26 & 4 & 7 & 4 & 7 & 47 & 85 & 43.472 & $0.001^{*}$ \\
\hline Pharmacovigilance/ADE/ADR reporting & 5 & 7 & 33 & 49 & 30 & 44 & 2 & 4 & 23 & 42 & 30 & 55 & 1.851 & 0.396 \\
\hline Drug therapy monitoring & 8 & 12 & 36 & 53 & 24 & 35 & 9 & 16 & 28 & 51 & 18 & 33 & 0.589 & 0.745 \\
\hline Medicines reconciliation/history & 13 & 19 & 29 & 43 & 26 & 38 & 12 & 22 & 14 & 25 & 29 & 53 & 4.499 & 0.105 \\
\hline Involvement in clinical trials & 54 & 79 & 14 & 21 & 0 & 0 & 23 & 42 & 22 & 40 & 10 & 18 & 23.143 & $0.001^{*}$ \\
\hline Patient education \& counselling & 0 & 0 & 3 & 4 & 65 & 96 & 0 & 0 & 4 & 7 & 51 & 93 & 0.464 & 0.496 \\
\hline Discharge counselling & 18 & 26 & 29 & 43 & 21 & 31 & 7 & 13 & 17 & 31 & 31 & 56 & 8.616 & $0.013^{*}$ \\
\hline Drug utilization evaluation \& review & 20 & 29 & 29 & 43 & 19 & 28 & 6 & 11 & 19 & 35 & 30 & 55 & 10.838 & $0.004^{*}$ \\
\hline Aseptic services & 34 & 50 & 22 & 32 & 12 & 18 & 16 & 29 & 23 & 42 & 16 & 29 & 5.764 & 0.056 \\
\hline $\begin{array}{l}\text { Parenteral nutrition support (TPN and } \\
\text { enteral feeds) }\end{array}$ & 41 & 60 & 15 & 22 & 12 & 18 & 23 & 42 & 18 & 33 & 14 & 25 & 4.162 & 0.125 \\
\hline
\end{tabular}


medRxiv preprint doi: https://doi.org/10.1101/2021.06.17.21258942; this version posted June 21, 2021. The copyright holder for this preprint (which was not certified by peer review) is the author/funder, who has granted medRxiv a license to display the preprint in perpetuity.

It is made available under a CC-BY-NC-ND 4.0 International license .

The results also showed disparity in the availability of clinical pharmacy services across the six geopolitical regions $(V=1.293, F=1.570, P=0.001)$. Post-hoc analysis indicated that pharmacists in more of the North Central and South West hospitals ( $n=5(26 \%), 9(36 \%)$, respectively) were routinely involved in multidisciplinary ward rounds compared to the other regions with fewer than $5 \%$ each. The North Central, South West and South South respondents were more likely to respectively report routine availability of medication chart review $(n=12(58 \%), 8(35 \%), 10(43 \%))$ and therapeutic guideline development services $(n=6(32 \%), 6(26 \%), 8(35 \%))$, compared to the other regions with fewer than $10 \%$ each. Although most of the hospitals in the North Central, North East, North West and South West regions provided compounding/extemporaneous preparation services ( $n=16(79 \%), 11(56 \%), 12(52 \%), 12(52 \%)$, respectively); fewer than half of those in the South East and South South ( $n=5(31 \%), 10(43 \%)$, respectively) reported this. Medication error services were reported by more than half of the North Central, North East, South South and South West $(n=13(63 \%), 11(55 \%), 12(52 \%), 17(70 \%)$, respectively) respondents compared with only about a third in the North West and South East region $(n=7(30 \%)$, $4(25 \%)$, respectively).

\section{Respondents' perception of practice}

Overall, only a few of the respondents $(\leq 30 \%)$ agreed that the available technology in the pharmacy department, the continuous professional development (CPD) opportunities, and the pharmacists' influence on prescribing was adequate or satisfactory at the respective hospitals (Table 4). This perception was not associated with the level of care provided in the hospitals $(p>0.05)$. More than half of those in the tertiary care compared to a smaller proportion in the secondary care hospitals, agreed that the pharmacy department had the right skills mix with satisfactory opportunities for developing expertise in hospital pharmacy practice (Table 4). However, this difference in perception was not statistically Significant $(p>0.05)$ (Table 4). The majority of the tertiary $(n=48(87 \%))$ and secondary care $(n=53(78 \%))$ respondents agreed that interdisciplinary collaboration in the hospital will raise the profile of the pharmacy department (Table 4). Generally, respondents' perceptions of practice within the respective levels of care were comparative across the six geopolitical regions $(V=0.333, F=0.888, p=0.681)$. 


\begin{tabular}{|c|c|c|c|c|c|c|c|c|c|c|c|c|c|c|}
\hline \multirow[t]{4}{*}{ Pharmacists' perceptions of practice } & \multicolumn{12}{|c|}{ Hospital Level of Care } & \multirow{4}{*}{$x^{2}$} & \multirow{4}{*}{$\mathbf{P}$} \\
\hline & \multicolumn{6}{|c|}{ Secondary $(N=68)$} & \multicolumn{6}{|c|}{ Tertiary $(\mathrm{N}=55)$} & & \\
\hline & \multicolumn{2}{|c|}{ Disagree } & \multicolumn{2}{|c|}{ Neutral } & \multicolumn{2}{|c|}{ Agree } & \multicolumn{2}{|c|}{ Disagree } & \multicolumn{2}{|c|}{ Neutral } & \multicolumn{2}{|c|}{ Agree } & & \\
\hline & $\mathrm{n}$ & $\%$ & $\mathrm{n}$ & $\%$ & $\mathrm{n}$ & $\%$ & $\mathrm{n}$ & $\%$ & & $\%$ & & $\%$ & & \\
\hline $\begin{array}{l}\text { The technology in this pharmacy is adequate } \\
\text { to support the provision of high quality } \\
\text { pharmacy services }\end{array}$ & 34 & 50 & 22 & 32 & 12 & 18 & 16 & 29 & 22 & 40 & 17 & 31 & 7.07 & 0.070 \\
\hline $\begin{array}{l}\text { The pharmacy team has satisfactory } \\
\text { influence over the policymakers and } \\
\text { managers within the hospital }\end{array}$ & 17 & 25 & 17 & 25 & 34 & 50 & 20 & 36 & 24 & 44 & 11 & 20 & 11.953 & $0.003 *$ \\
\hline $\begin{array}{l}\text { More joint professional working and } \\
\text { interdisciplinary collaboration would raise } \\
\text { the profile of this hospital pharmacy team }\end{array}$ & 0 & 0 & 15 & 22 & 53 & 78 & 2 & 4 & 5 & 9 & 48 & 87 & 5.940 & 0.051 \\
\hline $\begin{array}{l}\text { We have the right mix of skills and } \\
\text { qualifications among our staff to provide } \\
\text { our current services }\end{array}$ & 9 & 13 & 2 & 35 & 35 & 51 & 7 & 13 & 10 & 18 & 38 & 69 & 4.818 & 0.090 \\
\hline $\begin{array}{l}\text { Staff here have many opportunities to } \\
\text { develop high levels of expertise in general } \\
\text { hospital pharmacy practice }\end{array}$ & 16 & 24 & 22 & 32 & 30 & 44 & 6 & 11 & 19 & 35 & 30 & 55 & 3.429 & 0.180 \\
\hline $\begin{array}{l}\text { Staff here have many opportunities to } \\
\text { develop high levels of expertise in specific } \\
\text { clinical areas of hospital pharmacy practice }\end{array}$ & 19 & 28 & 20 & 29 & 29 & 43 & 9 & 16 & 19 & 35 & 27 & 49 & 2.320 & 0.313 \\
\hline $\begin{array}{l}\text { There are many in-house CPD opportunities } \\
\text { for staff }\end{array}$ & 25 & 37 & 25 & 37 & 18 & 26 & 20 & 36 & 18 & 33 & 17 & 31 & 0.354 & 0.838 \\
\hline $\begin{array}{l}\text { Hospital pharmacists are responsible and } \\
\text { accountable for patients' medication- } \\
\text { related outcomes in this hospital }\end{array}$ & 16 & 24 & 25 & 37 & 27 & 40 & 6 & 11 & 21 & 38 & 28 & 51 & 3.577 & 0.167 \\
\hline $\begin{array}{l}\text { Hospital pharmacists significantly influence } \\
\text { the prescribing practice in this hospital }\end{array}$ & 20 & 29 & 21 & 31 & 27 & 40 & 19 & 35 & 24 & 44 & 12 & 22 & 6.961 & 0.138 \\
\hline
\end{tabular}


medRxiv preprint doi: https://doi.org/10.1101/2021.06.17.21258942; this version posted June 21, 2021. The copyright holder for this preprint (which was not certified by peer review) is the author/funder, who has granted medRxiv a license to display the preprint in perpetuity.

It is made available under a CC-BY-NC-ND 4.0 International license .

\section{DISCUSSION}

Pharmacists' are essential for attaining the goal of universal health coverage and equitable access to essential health services, particularly with respect to optimizing the safe and responsible use of medicines [28]. Existing reports indicate that pharmaceutical care services and medicines-related activities are carried out by non-pharmacists in the majority of the PHCs in Nigeria $[23,29,30]$. This was observed in our study as pharmacists were employed in only a fraction of the primary care facilities. This finding highlights the need to prioritize the integration of clinical pharmacists within the primary care system in Nigeria. This is essential, given the evidence from other countries that demonstrate the effectiveness of pharmacistled primary care interventions in long term disease prevention, medication therapy management, and improvement in drug-related patient outcomes [31,32].

Although outpatient clinics with significant pharmacist input beyond dispensing were available in about two-thirds of the hospitals in our survey; the disparity in service availability within the specific levels of care and across the various geopolitical regions indicate the need for national scale up. Several factors including significant workforce shortages, high attrition rate, poor remuneration and funding, and the available pharmacists' expertise are some of the factors reported to limit uptake of clinical pharmacy services in countries in Africa including Nigeria [9,12,18,33-35]. This may explain why some of the clinical pharmacy services assessed in this survey were more likely to be available in the tertiary facilities compared to the secondary care hospitals; especially as the former tend to be larger, more funded and equipped with the capacity of employing more staff. On the other hand, this may also be related to the practice experience of the licensed pharmacists employed in the hospitals within the respective levels of care. Pharmacists in the tertiary care hospitals tended to be more experienced with a larger proportion possessing a post-graduate qualification or professional recognition. This suggests that the tertiary care pharmacists are more likely to have undertaken further post-registration training and are potentially more equipped to provide enhanced patient-oriented care services in their respective hospitals.

The finding that online medicine information services were not available in close to half of the secondary care hospitals highlights the need to improve the available information technology infrastructure in the respective hospitals. This is necessary, so as to ensure pharmacists' access to current medicines 
medRxiv preprint doi: https://doi.org/10.1101/2021.06.17.21258942; this version posted June 21, 2021. The copyright holder for this preprint (which was not certified by peer review) is the author/funder, who has granted medRxiv a license to display the preprint in perpetuity.

It is made available under a CC-BY-NC-ND 4.0 International license .

information resources, especially as existing evidence demonstrates that professional practice that is consistent with up-to-date knowledge influence patient safety and clinical outcomes [36]. This was also emphasized by the significant proportion of study respondents in both the tertiary and secondary care hospitals who indicated that the IT resources and CPD opportunities available were not adequate. More robust training infrastructure that would provide further opportunities for pharmacists to develop their skills and promote lifelong learning are therefore required in the country. Enhanced pharmaceutical care services such as medication chart review, medication error reporting, antibiotic stewardship programmes, and pharmacovigilance activities are important clinical services that impact patient outcomes $[2,37]$. Prioritizing pharmacists' involvement in these key services in Nigeria is crucial in order to safeguard patients' health, ensure medication safety, and limit drug interactions.

To the best of our knowledge, this is the first study to provide a comparative overview of the available clinical pharmacy services within the various levels of care and across the six geopolitical regions of Nigeria. The national scope of the study is a key strength, given the paucity of data in the subject area. However, given that this was a non-random survey, our study estimates though accurate, are unlikely to be a precise representation of the population of interest. Also, this study relied on respondents' report of the services available at their respective hospital. This approach is likely to have introduced bias associated with the use of self-administered questionnaires [38]. Despite these limitations, the broad similarities in service provision within the respective levels of care in our sample, provide an indication of the existing trends with respect to clinical pharmacy service availability across the states and geopolitical regions in the country.

\section{Conclusions}

This study provides evidence that was previously lacking with respect to the availability of clinical pharmacy services in public sector hospitals in Nigeria. The disparity in the availability of these services across the various levels of care highlight the need to scale up the uptake of these services nationally. Our findings also emphasize the need to prioritize the integration of clinical pharmacy services within the primary healthcare system, to ensure equitable access to medicines expertise and contribute to universal health coverage. The evidence in this study can inform national policy planning and development in the pharmaceutical sector in Nigeria, particularly in relation to ensuring the availability of enhanced patientoriented services. 
medRxiv preprint doi: https://doi.org/10.1101/2021.06.17.21258942; this version posted June 21, 2021. The copyright holder for this preprint (which was not certified by peer review) is the author/funder, who has granted medRxiv a license to display the preprint in perpetuity.

It is made available under a CC-BY-NC-ND 4.0 International license .

\section{References}

90 1. Obayendo T. Presidency Approves Consultant Pharmacist Cadre in Public Service. Pharmanewsonline 912020.

2. Rotta I, Salgado TM, Silva ML et al. Effectiveness of clinical pharmacy services: an overview of systematic reviews (2000-2010). Int J Clin Pharm 2015;37:687-97.

3. Carter BL. Evolution of Clinical Pharmacy in the USA and Future Directions for Patient Care. Drugs Aging 2016;33:169-77.

4. Canadian Society of Hospital Pharmacists. Hospital Pharmacy in Canada Report 2016/17. Ottawa, Canada: Canadian Society of Hospital Pharmacists, 2018.

5. Proper JS, Wong A, Plath AE et al. Impact of clinical pharmacists in the emergency department of an Australian public hospital: A before and after study. Emerg Med Australas 2015;27:232-8. Evolved from 2013 to 2017? Pharm Basel Switz 2020;8, DOI: 10.3390/pharmacy8010019.

7. The Pharmaceutical Society of Ireland. Baseline Study of Hospital Pharmacy in Ireland: Final Report. Dublin, Ireland: The Pharmaceutical Society of Ireland, 2012:205.

8. Elliott RA, Perera D, O'Leary K. National survey of clinical pharmacy services and pharmacy technician roles for subacute aged-care inpatients. J Pharm Pract Res 2012;42:125-8.

9. Hambisa S, Abie A, Nureye D et al. Attitudes, Opportunities, and Challenges for Clinical Pharmacy Services in Mizan-Tepi University Teaching Hospital, Southwest Ethiopia: Health Care Providers' Perspective. Adv Pharmacol Pharm Sci 2020;2020:e5415290.

10. Pawłowska I, Pawłowski L, Kocić I et al. Clinical and conventional pharmacy services in Polish hospitals: a national survey. Int J Clin Pharm 2016;38:271-9.

11. Yao D, Xi X, Huang Y et al. A national survey of clinical pharmacy services in county hospitals in China. PLOS ONE 2017;12:e0188354. qualitative exploration of stakeholders' views. J Eval Clin Pract 2016;22:699-706. Income Countries. Front Pharmacol 2020;11, DOI: 10.3389/fphar.2020.00978. 
medRxiv preprint doi: https://doi.org/10.1101/2021.06.17.21258942; this version posted June 21, 2021. The copyright holder for this preprint (which was not certified by peer review) is the author/funder, who has granted medRxiv a license to display the preprint in perpetuity. It is made available under a CC-BY-NC-ND 4.0 International license .

15. International Pharmaceutical Federation. Revised FIP Basel Statements on the Future of Hospital Pharmacy. The Hague, Netherlands: International Pharmaceutical Federation, 2014:6.

16. Penm J, Moles R. Global developments in hospital pharmacy: the revised Basel statements. J Pharm Pract Res 2016;46:301-3.

17. Ekpenyong A, Udoh A, Kpokiri E et al. An analysis of pharmacy workforce capacity in Nigeria. J Pharm Policy Pract 2018;11:20.

18. Ma'aji HU, Khan F, Shuaibu A et al. Assessment of Hospital Pharmacy Services in North Western Nigeria. Niger J Pharm Sci 2018;17:90-7.

19. The World Bank. Population, total - Nigeria | Data. 2019.

20. International Organization for Migration. Needs Assessment of the Nigerian Health Sector. Abuja, Nigeria: International Organization for Migration, 2014:47.

21. Kombe G, Fleisher L, Kariisa E et al. Nigeria Health System Assessment. Bethesda, MD: United States Agency for International Development and Abt Associates Inc., 2009.

22. National Primary Health Care Development Agency. Report of the Expert Group on Revitalization of Primary Health Care In Nigeria. Abuja, Nigeria: National Primary Health Care Development Agency, 2015:97.

23. Alliance for Health Policy and Systems Research. Primary Care Systems Profiles and Performance (PRIMASYS). Geneva, Switzerland: Alliance for Health Policy and Research, The Bill \& Melinda Gates Foundation and World Health Organization, 2016:8.

24. Asuzu M. The necessity for a health system reform in Nigeria. J Community Med Prim Health Care 2004;16:1-3.

25. Federal Ministry of Health. Distribution of Hospitals and Clinics in Nigeria. Niger Health Facil Regist HFR 2017.

26. Olson CL. Comparative Robustness of Six Tests in Multivariate Analysis of Variance. J Am Stat Assoc 1974;69:894-908.

27. Eysenbach G. Improving the Quality of Web Surveys: The Checklist for Reporting Results of Internet ESurveys (CHERRIES). J Med Internet Res 2004;6:e34.

28. Udoh A, Ernawati DK, Akpan M et al. Pharmacies and primary care: a global development framework. Bull World Health Organ 2020;98:809-11.

29. Alenoghena I, Aigbiremolen A, Abejegah C et al. Primary Health Care in Nigeria: Strategies and Constraints in Implementation. Int J Community Res 2014;3:74-9. 
medRxiv preprint doi: https://doi.org/10.1101/2021.06.17.21258942; this version posted June 21, 2021. The copyright holder for this preprint (which was not certified by peer review) is the author/funder, who has granted medRxiv a license to display the preprint in perpetuity.

It is made available under a CC-BY-NC-ND 4.0 International license .

30. Christian Aid. Assessment of Primary Health Centres in Selected States of Nigeria: Summary Report of Findings from Christian Aid Supported Communities in Anambra, Benue, Kaduna, Plateau States and the Federal Capital Territory (FCT). Abuja, Nigeria: Christian Aid, 2015:38.

31. Tan ECK, Stewart K, Elliott RA et al. Pharmacist services provided in general practice clinics: a systematic review and meta-analysis. Res Soc Adm Pharm RSAP 2014;10:608-22.

32. Avery AJ, Rodgers S, Cantrill JA et al. A pharmacist-led information technology intervention for medication errors (PINCER): a multicentre, cluster randomised, controlled trial and cost-effectiveness analysis. Lancet Lond Engl 2012;379:1310-9.

33. Adibe M, Victoria U. Assessment of Hospital Pharmacy Services in South-Eastern Nigeria. Int J Pharmagenesis 2010;1:209-15.

34. Bilal Al, Tilahun Z, Gebretekle GB et al. Current status, challenges and the way forward for clinical pharmacy service in Ethiopian public hospitals. BMC Health Serv Res 2017;17:359.

35. Salim AA, Elhada AA, Elgizoli B. Exploring clinical pharmacists' perception of their impact on healthcare in Khartoum State, Sudan. J Res Pharm Pract 2016;5:272.

36. Institute of Medicine. To Err Is Human: Building a Safer Health System. Washington DC: National Academy Press, 2000.

37. Ourghanlian C, Lapidus N, Antignac $\mathrm{M}$ et al. Pharmacists' role in antimicrobial stewardship and relationship with antibiotic consumption in hospitals: An observational multicentre study. J Glob Antimicrob Resist 2020;20:131-4.

38. Demetriou C, Ozer BU, Essau CA. Self-Report Questionnaires. The Encyclopedia of Clinical Psychology. American Cancer Society, 2015, 1-6.

\section{Funding}

This research received no specific grant from any funding agency in the public, commercial, or not-forprofit sectors

\section{Conflict of Interest}

None declared

\section{Author contribution}

- $\mathrm{AU}$ - Conceptualization, methodology, data curation, formal analysis, original draft preparation 
medRxiv preprint doi: https://doi.org/10.1101/2021.06.17.21258942; this version posted June 21, 2021. The copyright holder for this preprint (which was not certified by peer review) is the author/funder, who has granted medRxiv a license to display the preprint in perpetuity.

It is made available under a CC-BY-NC-ND 4.0 International license .

- EN, EK, UO, MA, UII - Conceptualization, methodology, data curation, validation, writing review and editing

181 Acknowledgment

182 The authors would like to thank the Association of Hospital and Administrative Pharmacists of Nigeria

183 (AHAPN), the Pharmaceutical Society of Nigeria (PSN) and Olutope Arinola Akinnibosun for assisting with

184 the data collection in this study.

Table Legend

- Table 1: Hospital profile and demography

187

- Table 2: Pharmacy department profile

- Table 3: Availability of clinical pharmacy services

- Table 4: Respondents' perceptions of practice and available resources 
medRxiv preprint doi: https://doi.org/10.1101/2021.06.17.21258942; this version posted June 21, 2021. The copyright holder for this preprint (which was not certified by peer review) is the author/funder, who has granted medRxiv a license to display the preprint in perpetuity.

\begin{tabular}{|c|c|c|c|}
\hline $\mathrm{S} / \mathrm{N}$ & Name of Facility & $\begin{array}{l}\text { State/Locatio } \\
\mathrm{n}\end{array}$ & Region \\
\hline 1 & GH Isiukwuato & Abia & South East \\
\hline 2 & GH Ohafia & Abia & South East \\
\hline 3 & Federal Medical Centre,Umuahia, Abia State & Abia & South East \\
\hline 4 & Mkpakpi Utotu, Arochkwu & Abia & South East \\
\hline 5 & Ndundu, Isiukwu Ato & Abia & South East \\
\hline 6 & PHC Etit Ohazu & Abia & South East \\
\hline 7 & Primary Health Centre, Umuebeke & Abia & South East \\
\hline 8 & Mubi GH & Adamawa & North East \\
\hline 9 & Numan GH & Adamawa & North East \\
\hline 10 & Adamawa German Medical Centre Yola & Adamawa & North East \\
\hline 11 & Federal Medical Centre, Yola, Adamawa State & Adamawa & North East \\
\hline 12 & Bazza PHCc, Michika & Adamawa & North East \\
\hline 13 & Gombi A PHCc & Adamawa & North East \\
\hline 14 & Gwadabawa PHC, Jimeta & Adamawa & North East \\
\hline 15 & Wuro Hausa PHCc, Yola Town & Adamawa & North East \\
\hline 16 & $\begin{array}{l}\text { General Hospital, Ikot Okoro. Oruk Anam Local Gov't Area. } \\
\text { Akwa Ibom State }\end{array}$ & Akwa Ibom & South South \\
\hline 17 & General Hospital Iquita, Oron & Akwa Ibom & South South \\
\hline 18 & University of Uyo Teaching Hospital & Akwa Ibom & South South \\
\hline 19 & PHC Ukpom-Abak & Akwa Ibom & South South \\
\hline 20 & Primary Health Centre, Ikot Oku Ubo & Akwa Ibom & South South \\
\hline 21 & Primary Health Centre, Nwaniba, Uruan & Akwa Ibom & South South \\
\hline 22 & Primary Healthcare-Based Centre & Akwa Ibom & South South \\
\hline 23 & General Hospital Ekwulobia & Anambra & South East \\
\hline 24 & General Hospital, Onitsha & Anambra & South East \\
\hline 25 & Nauth & Anambra & South East \\
\hline 26 & Ukunu Primary Health Centre & Anambra & South East \\
\hline 27 & Maternal and Children Health Clinic, Amawbia & Anambra & South East \\
\hline 28 & Primary Health Centre, Nise & Anambra & South East \\
\hline 29 & Primary Health Centre, Umunnachi & Anambra & South East \\
\hline 30 & GH Ningi & Bauchi & North East \\
\hline 31 & Federal Medical Centre Azare & Bauchi & North East \\
\hline 32 & PHC Buscuri & Bauchi & North East \\
\hline 33 & PHC Buzaye & Bauchi & North East \\
\hline 34 & PHC Dindima & Bauchi & North East \\
\hline 35 & PHC Gada Mewa & Bauchi & North East \\
\hline 36 & General Hospital Amassoma & Bayelsa & South South \\
\hline 37 & Odi General Hospital & Bayelsa & South South \\
\hline 38 & Bayelsa Specialist Hospital & Bayelsa & South South \\
\hline
\end{tabular}


medRxiv preprint doi: https://doi.org/10.1101/2021.06.17.21258942; this version posted June 21, 2021. The copyright holder for this preprint (which was not certified by peer review) is the author/funder, who has granted medRxiv a license to display the preprint in perpetuity.

\begin{tabular}{|c|c|c|c|}
\hline 39 & Federal Medical Centre, Yenagoa, Bayelsa State. & Bayelsa & South South \\
\hline 40 & Niger Delta Univerity Teaching Hospital Bayelsa & Bayelsa & South South \\
\hline 41 & Ekweremo Primary Health Centre & Bayelsa & South South \\
\hline 42 & PHC Azikoro & Bayelsa & South South \\
\hline 43 & Yenizue PHC & Bayelsa & South South \\
\hline 44 & GH Otukpo & Benue & North Central \\
\hline 45 & Ugba GH & Benue & North Central \\
\hline 46 & Fmc Makurdi & Benue & North Central \\
\hline 47 & Chc Yogbo, Guma & Benue & North Central \\
\hline 48 & Comprehensive Health Care Center, Gboko North & Benue & North Central \\
\hline 49 & PHC Agede, Akurdi & Benue & North Central \\
\hline 50 & PHC Otobi, Otukpo & Benue & North Central \\
\hline 51 & GH Gwoza & Borno & North East \\
\hline 52 & University of Maiduguri Teaching Hospital & Borno & North East \\
\hline 53 & Gora Dispensary & Borno & North East \\
\hline 54 & Tikka Dispensary & Borno & North East \\
\hline 55 & Tobule Health Clinic & Borno & North East \\
\hline 56 & Zonal Health Office & Borno & North East \\
\hline 57 & General Hospital Calabar & Cross River & South South \\
\hline 58 & GH Akim & Cross River & South South \\
\hline 59 & University of Calabar Teaching Hospital, Calabar. & Cross River & South South \\
\hline 60 & Abenyo Health Post & Cross River & South South \\
\hline 61 & Akansoko Clinic, Akpabuyo & Cross River & South South \\
\hline 62 & Akpoha Health Post, Abi & Cross River & South South \\
\hline 63 & Primary Health Centre, Akim Calabar Municipality & Cross River & South South \\
\hline 64 & GH Ogbara & Delta & South South \\
\hline 65 & Otor-Udu GH & Delta & South South \\
\hline 66 & DELSUTH & Delta & South South \\
\hline 67 & Federal Medical Centre Asaba & Delta & South South \\
\hline 68 & FUPR Health Centre & Delta & South South \\
\hline 69 & Ifie PHC & Delta & South South \\
\hline 70 & Govt Unit Hospital Umutu & Delta & South South \\
\hline 71 & PHC Adonte & Delta & South South \\
\hline 72 & GH Okposi & Ebonyi & South East \\
\hline 73 & GH Onueke & Ebonyi & South East \\
\hline 74 & Federal Teaching Hospital Abakaliki Ebonyi State & Ebonyi & South East \\
\hline 75 & Eguto Health Centre & Ebonyi & South East \\
\hline 76 & Ndienyi Health Post & Ebonyi & South East \\
\hline 77 & Okaria Health Post & Ebonyi & South East \\
\hline 78 & Orona Health Centre & Ebonyi & South East \\
\hline
\end{tabular}


medRxiv preprint doi: https://doi.org/10.1101/2021.06.17.21258942; this version posted June 21, 2021. The copyright holder for this preprint (which was not certified by peer review) is the author/funder, who has granted medRxiv a license to display the preprint in perpetuity.

\begin{tabular}{|c|c|c|c|}
\hline 79 & General Hospital Ekpoma & Edo & South South \\
\hline 80 & GH Afueze & Edo & South South \\
\hline 81 & Irrua Specialist Teaching Hospital & Edo & South South \\
\hline 82 & University of Benin Teaching Hospital & Edo & South South \\
\hline 83 & Ohe Primary Health Centre & Edo & South South \\
\hline 84 & Bekuma Health Post & Edo & South South \\
\hline 85 & Idoa PHC & Edo & South South \\
\hline 86 & Uneven Health Center & Edo & South South \\
\hline 87 & Ode GH & Ekiti & South West \\
\hline 88 & State Specialist Hospital Ikole Ekiti & Ekiti & South West \\
\hline 89 & Federal Teaching Hospital, Ido Ekiti & Ekiti & South West \\
\hline 90 & Okeseri Health Centre & Ekiti & South West \\
\hline 91 & Ajebadmidele Health Post & Ekiti & South West \\
\hline 92 & Basic Health Centre Irele & Ekiti & South West \\
\hline 93 & Odo Basic Health Clinic & Ekiti & South West \\
\hline 94 & Medical Centre, University of Nigeria Enugu Campus. & Enugu & South East \\
\hline 95 & Enugu State Teaching Hospital, Parklane, Enugu State & Enugu & South East \\
\hline 96 & $\begin{array}{l}\text { University of Nigeria Teaching Hospital Ituku-Ozalla, Enugu, } \\
\text { Enugu State. }\end{array}$ & Enugu & South East \\
\hline 97 & PHC Abakpa Nike & Enugu & South East \\
\hline 98 & PHC Awgu Lga & Enugu & South East \\
\hline 99 & PHC Ndi-Uno Uwani Akpugo & Enugu & South East \\
\hline 100 & PHC Nomeh, Nkanu East & Enugu & South East \\
\hline 101 & Garki Hospital, Abuja. & FCT & North Central \\
\hline 102 & NNPC Clinic & FCT & North Central \\
\hline 103 & UATH, Gwagwalada & FCT & North Central \\
\hline 104 & Federal Medical Centre, Jabi, Airport Road, Abuja & FCT & North Central \\
\hline 105 & National Hospital Abuja & FCT & North Central \\
\hline 106 & Kuje PHC & FCT & North Central \\
\hline 107 & Nanda PHC Gwagwalada & FCT & North Central \\
\hline 108 & PHC Bwari & FCT & North Central \\
\hline 109 & PHC Lugbe & FCT & North Central \\
\hline 110 & Cottage Hospital Hinna & Gombe & North East \\
\hline 111 & State Specialist Hospital Gombe & Gombe & North East \\
\hline 112 & Nafada Health Care Center, Nafada & Gombe & North East \\
\hline 113 & Billirin Comprehensive Health Center, Billiri & Gombe & North East \\
\hline 114 & Manawachi Health Post & Gombe & North East \\
\hline 115 & Primary Health Care Center,Pantami,Gombe State. & Gombe & North East \\
\hline 116 & GH Oguta & Imo & South East \\
\hline 117 & Imo State Specialist Hospital, Owerri & Imo & South East \\
\hline
\end{tabular}


medRxiv preprint doi: https://doi.org/10.1101/2021.06.17.21258942; this version posted June 21, 2021. The copyright holder for this preprint (which was not certified by peer review) is the author/funder, who has granted medRxiv a license to display the preprint in perpetuity.

\begin{tabular}{|c|c|c|c|}
\hline 118 & Imsuth & Imo & South East \\
\hline 119 & Federal Medical Centre, Owerri & Imo & South East \\
\hline 120 & Akima Health Centre, Oru East & Imo & South East \\
\hline 121 & Egbelu Umuhu Health Centre & Imo & South East \\
\hline 122 & Omata Health Post & Imo & South East \\
\hline 123 & PHC Umuguma & Imo & South East \\
\hline 124 & Gumel General Hospital, Gumel Jigawa & Jigawa & North West \\
\hline 125 & Hadejia General Hospital & Jigawa & North West \\
\hline 126 & Federal Medical Center, Birnin Kudu, Jigawa State & Jigawa & North West \\
\hline 127 & Sagu Primary Health Centre & Jigawa & North West \\
\hline 128 & Kawaya Health Post & Jigawa & North West \\
\hline 129 & Sabon Hari Taura Health Post & Jigawa & North West \\
\hline 130 & Walawa Maternity Clinic & Jigawa & North West \\
\hline 131 & Ahmadu Bello University Teaching Hospital, Zaria & Kaduna & North West \\
\hline 132 & Gambo Sawaba General Hospital & Kaduna & North West \\
\hline 133 & Yusuf Dantsoho Memorial Hospital,Kaduna & Kaduna & North West \\
\hline 134 & Barau Dikko Teaching Hospital & Kaduna & North West \\
\hline 135 & National Ear Care Centre Kaduna & Kaduna & North West \\
\hline 136 & Nigerian Defence Academy Hospital Kaduna & Kaduna & North West \\
\hline 137 & PHC Jaji & Kaduna & North West \\
\hline 138 & PHC Mando & Kaduna & North West \\
\hline 139 & PHC Unguwan Rimi & Kaduna & North West \\
\hline 140 & Infectious Diseases Hospital & Kano & North West \\
\hline 141 & Muhammed Abdullahi Wase Teaching Hospital & Kano & North West \\
\hline 142 & Aminu Kano Teaching Hospital & Kano & North West \\
\hline 143 & Baburi Health Post, Tundu Wada & Kano & North West \\
\hline 144 & Fragawa Health Post & Kano & North West \\
\hline 145 & Guzurawa Health Clinic, Kano & Kano & North West \\
\hline 146 & Madine Health Post, Bichi & Kano & North West \\
\hline 147 & Sarkin Maska Shehu Hospital & Katsina & North West \\
\hline 148 & $\begin{array}{l}\text { Turai Umar Yar'adua Maternity and Children Hospital } \\
\text { Katsina }\end{array}$ & Katsina & North West \\
\hline 149 & Federal Medical Centre Katsina & Katsina & North West \\
\hline 150 & Family Support Clinic & Katsina & North West \\
\hline 151 & Aya Health Clinic, Baure & Katsina & North West \\
\hline 152 & Dadin Kowa Health Centre & Katsina & North West \\
\hline 153 & Gidan Bakoshi Health Clinic & Katsina & North West \\
\hline 154 & GH Bagudo & Kebbi & North West \\
\hline 155 & GH Magaji & Kebbi & North West \\
\hline 156 & Maternal Child Health, Rafin Zuru & Kebbi & North West \\
\hline
\end{tabular}


medRxiv preprint doi: https://doi.org/10.1101/2021.06.17.21258942; this version posted June 21, 2021. The copyright holder for this preprint (which was not certified by peer review) is the author/funder, who has granted medRxiv a license to display the preprint in perpetuity.

\begin{tabular}{|c|c|c|c|}
\hline 157 & Boko PHC & Kebbi & North West \\
\hline 158 & Geza Health Post & Kebbi & North West \\
\hline 159 & Tungar Yawo PHC & Kebbi & North West \\
\hline 160 & GH Kaba & Kogi & North Central \\
\hline 161 & General Hospital Mopa-Muro & Kogi & North Central \\
\hline 162 & Federal Medical Centre Lokoja & Kogi & North Central \\
\hline 163 & Ojeh PHC & Kogi & North Central \\
\hline 164 & Okikili PHC & Kogi & North Central \\
\hline 165 & PHC Gboloke & Kogi & North Central \\
\hline 166 & PHC Eni Magongo & Kogi & North Central \\
\hline 167 & General Hospital Ilorin & Kwara & North Central \\
\hline 168 & University of Ilorin Teaching Hospital & Kwara & North Central \\
\hline 169 & Babana Dispensary & Kwara & North Central \\
\hline 170 & Baruten Health Post \& Dispensary & Kwara & North Central \\
\hline 171 & Health Post Bayagen & Kwara & North Central \\
\hline 172 & Okelele & Kwara & North Central \\
\hline 173 & Ajeromi General Hospital & Lagos & South West \\
\hline 174 & Federal Neuropsychiatric Hospital Yaba Lagos & Lagos & South West \\
\hline 175 & Lagos State University Teaching Hospital, Ikeja Lagos & Lagos & South West \\
\hline 176 & Lagos University Teaching Hospital, Idi-Araba Lagos & Lagos & South West \\
\hline 177 & National Orthopaedic Hospital Igbobi Lagos & Lagos & South West \\
\hline 178 & Nigerian Institute Of Medical Research & Lagos & South West \\
\hline 179 & GH Epe & Lagos & South West \\
\hline 180 & Mainland Hospital Yaba & Lagos & South West \\
\hline 181 & Debojo Primary Health Centre & Lagos & South West \\
\hline 182 & Majidun Primary Health Centre & Lagos & South West \\
\hline 183 & Harvey Road Health Centre And Maternity & Lagos & South West \\
\hline 184 & Itokin Primary Health Centre & Lagos & South West \\
\hline 185 & GH Uke & Nasarawa & North Central \\
\hline 186 & Keffi GH & Nasarawa & North Central \\
\hline 187 & Federal Medical Centre Keffi & Nasarawa & North Central \\
\hline 188 & PHC Akwanga & Nasarawa & North Central \\
\hline 189 & PHC Angwa Toni, Lafia & Nasarawa & North Central \\
\hline 190 & PHC Doma, & Nasarawa & North Central \\
\hline 191 & PHC Garaku & Nasarawa & North Central \\
\hline 192 & General Hospital Kontagora & Niger & North Central \\
\hline 193 & General Hospital Minna & Niger & North Central \\
\hline 194 & Federal Medical Centre, Bida & Niger & North Central \\
\hline 195 & Efun Madami PHC, Bida & Niger & North Central \\
\hline 196 & PHC Agaie & Niger & North Central \\
\hline
\end{tabular}


medRxiv preprint doi: https://doi.org/10.1101/2021.06.17.21258942; this version posted June 21, 2021. The copyright holder for this preprint (which was not certified by peer review) is the author/funder, who has granted medRxiv a license to display the preprint in perpetuity.

\begin{tabular}{|c|c|c|c|}
\hline 197 & PHC Kuta, Shiroro Lga & Niger & North Central \\
\hline 198 & PHC Waw Road, New Bussa & Niger & North Central \\
\hline 199 & GH Omu & Ogun & South West \\
\hline 200 & Olikoye Ransom Kuti Memorial Hospital Asero Abeokuta & Ogun & South West \\
\hline 201 & Federal Medical Centre Abeokuta & Ogun & South West \\
\hline 202 & Olabisi Onabanjo University Teaching Hospital & Ogun & South West \\
\hline 203 & Iwopin Comprehensive Health Centre & Ogun & South West \\
\hline 204 & Cresent Medical Centre & Ogun & South West \\
\hline 205 & Fagberno PHC & Ogun & South West \\
\hline 206 & ljeja Model Clinic & Ogun & South West \\
\hline 207 & Otun PHC & Ogun & South West \\
\hline 208 & GH Akure & Ondo & South West \\
\hline 209 & General Hospital Ipe & Ondo & South West \\
\hline 210 & FMC Owo & Ondo & South West \\
\hline 211 & Agamo Primary Health Clinic & Ondo & South West \\
\hline 212 & Ipori Primary Health Clinic & Ondo & South West \\
\hline 213 & Health Centre Ise & Ondo & South West \\
\hline 214 & GH Osogbo & Osun & South West \\
\hline 215 & State Hospital Ede & Osun & South West \\
\hline 216 & Ladoke Akintola University Teaching Hospital & Osun & South West \\
\hline 217 & Model Primary Health Centre, Iresi & Osun & South West \\
\hline 218 & Aladodo PHC & Osun & South West \\
\hline 219 & Ogo-Oluwa PHC & Osun & South West \\
\hline 220 & Mokore Primary Health Centre & Osun & South West \\
\hline 221 & Tede General & Oyo & South West \\
\hline 222 & GH Okaka & Oyo & South West \\
\hline 223 & University College Hospital, Ibadan & Oyo & South West \\
\hline 224 & Olode PHC & Oyo & South West \\
\hline 225 & Asaju Primary Health Centre & Oyo & South West \\
\hline 226 & Olode Primary Health Centre & Oyo & South West \\
\hline 227 & Iregba Primary Health Centre & Oyo & South West \\
\hline 228 & Jos University Teaching Hospital (Juth) & Plateau & North Central \\
\hline 229 & Primary Health Care Centre, Daddin Kowa & Plateau & North Central \\
\hline 230 & Primary Health Care Centre, Dogon Dutse & Plateau & North Central \\
\hline 231 & Primary Health Care Centre, Jos Jarawa & Plateau & North Central \\
\hline 232 & Primary Health Care Centre, Jos Township & Plateau & North Central \\
\hline 233 & Govt House Clinic PHC & Rivers & South South \\
\hline 234 & GH Degema & Rivers & South South \\
\hline 235 & Rivers State University Teaching Hospital Port Harcourt & Rivers & South South \\
\hline
\end{tabular}


medRxiv preprint doi: https://doi.org/10.1101/2021.06.17.21258942; this version posted June 21, 2021. The copyright holder for this preprint (which was not certified by peer review) is the author/funder, who has granted medRxiv a license to display the preprint in perpetuity.

\begin{tabular}{|c|c|c|c|}
\hline 236 & University Of Port Harcourt Teaching Hospital & Rivers & South South \\
\hline 237 & Egendem Health Clinic & Rivers & South South \\
\hline 238 & Isiodu Health Centre & Rivers & South South \\
\hline 239 & $\begin{array}{l}\text { Lulu Briggs Health Centre, University Of Port Harcourt, } \\
\text { Rivers, Nigeria }\end{array}$ & Rivers & South South \\
\hline 240 & Medical Center, Rivers State University & Rivers & South South \\
\hline 241 & Dogon Daji & Sokoto & North West \\
\hline 242 & Infectious Diseases Hospital Amanawa, Sokoto. & Sokoto & North West \\
\hline 243 & Specialist Hospital Sokoto & Sokoto & North West \\
\hline 244 & Usaman Danfodio University Teaching Hospital Sokoto & Sokoto & North West \\
\hline 245 & Chilas PHC & Sokoto & North West \\
\hline 246 & Katanga PHC & Sokoto & North West \\
\hline 247 & Tarke Health Post & Sokoto & North West \\
\hline 248 & Tsitse Health Clinic & Sokoto & North West \\
\hline 249 & First Referral Hospital Baissa & Taraba & North East \\
\hline 250 & First Referral Hospital Serti & Taraba & North East \\
\hline 251 & General Hospital Gembu & Taraba & North East \\
\hline 252 & Government House Clinic & Taraba & North East \\
\hline 253 & Federal Medical Centre,Jalingo & Taraba & North East \\
\hline 254 & Specialist Hospital Jalingo Taraba State & Taraba & North East \\
\hline 255 & Mayo-Gwoi Primary Health Centre, Jalingo & Taraba & North East \\
\hline 256 & Primary Health Centre, Chachanji & Taraba & North East \\
\hline 257 & Primary Health Centre, Kasuwa Ladi & Taraba & North East \\
\hline 258 & Primary Health Centre, Sabon Gida & Taraba & North East \\
\hline 259 & Dapchi GH & Yobe & North East \\
\hline 260 & GH Fika & Yobe & North East \\
\hline 261 & Federal Medical Centre, Nguru, Yobe State & Yobe & North East \\
\hline 262 & Yobe State University Teaching Hospital Damaturu & Yobe & North East \\
\hline 263 & Ningi Health Post & Yobe & North East \\
\hline 264 & Sagum Dispensary & Yobe & North East \\
\hline 265 & Yelwa Primary Health Clinic & Yobe & North East \\
\hline 266 & General Hospital Gusau & Zamfara & North West \\
\hline 267 & GH Maru & Zamfara & North West \\
\hline 268 & Federal Medical Center Gusau & Zamfara & North West \\
\hline 269 & Bawo Dispensary & Zamfara & North West \\
\hline 270 & PHC Birnin Mogaji & Zamfara & North West \\
\hline 271 & PHC Kurya, Shinkafi & Zamfara & North West \\
\hline 272 & PHC Talata Mafara & Zamfara & North West \\
\hline
\end{tabular}

